\title{
Formulasi Campuran Bahan Pengemulsi untuk Bolu Sponge
}

\section{Mixed Emulsifier Formula in Sponge Cake}

\author{
Hanifah Nuryani Lioe $^{1 *}$, Aida Fadhilah ${ }^{2)}$, Istiqamah ${ }^{2)}$ \\ ${ }^{1)}$ Departemen Ilmu dan Teknologi Pangan, Fakultas Teknologi Pertanian, Institut Pertanian Bogor, Bogor \\ ${ }^{2)}$ Quality Control and Quality Assurance Division, PT. Zeelandia Indonesia, Tangerang
}

\begin{abstract}
To make a sponge cake, a mix of emulsifiers provides an improved aeration. The aim of this research was to formulate the mix of distilled monoglycerides $(D M G)$ and polyglycerol esters (PGE), which had yellowish color, in a gel form for its application in sponge cake. The formula of the gel consists of primary and secondary food additives: $15.3 \%$ DMG, 6.5\% PGE, 25.8\% other emulsifiers and carrier including colorings (ponceau and tartrazine), 26.1\% sorbitol, and 26.3\% water. DMG and PGE had different colors from their expected standard color, white. The formula of DMG $(15.3 \%)$ and PGE $(6.5 \%)$ mix, comprising $21.8 \%$ of the formula above, was re-formulated by 100:0, 75:25, 50:50, 25:75, and 0:100 ratios of DMG to PGE. The physical characteristics of the formula consisting of color characteristic by chromameter, sensory score by R-Index method and gel spreadability were compared to the formula using standard materials of DMG and PGE. The formula was then applied for sponge cake. The specific gravity of sponge cake batter, height of sponge cake after baking, as well as sensory characteristics of crumb structure and crumb color of sponge cake were analyzed. The results of physical characterization of formula revealed that the use of $100 \%$ of PGE and the use of DMG up to 50\% did not significantly differ from the standard formula. The combination of DMG and PGE formula did not affect batter specific gravity, cake height and crumb structure, but affected color of the crumb.
\end{abstract}

Keywords: cake emulsifier, distilled monoglycerides, emulsifiers formula, polyglycerol ester, sponge cake

\begin{abstract}
Abstrak. Campuran pengemulsi diperlukan untuk pengembangan bolu sponge. Tujuan penelitian adalah untuk memformulasi campuran monogliserida terdistilasi (DMG) dan poligliserol ester (PGE), yang mempunyai warna kekuningan, dalam bentuk gel untuk aplikasi pada bolu sponge. Formula gel BTP campuran pengemulsi terdiri dari 15.3\% DMG, 6.5\% PGE, 25.8\% pengemulsi lain dan pembawa termasuk pewarna ponceau dan tartrazine, $26.1 \%$ sorbitol, dan 26.3\% air. Bahan DMG (15.3\%) dan PGE (6.5\%) dengan total 21.8\% diformulasi dengan rasio DMG terhadap PGE 100: 0, 75:25, 50:50, 25:75, dan 0: 100 . Karakteristik formula dibandingkan dengan formula standar. Karakteristik fisik yang dianalisis adalah warna dengan chromameter, skor sensori dengan metode R-Index dan spreadability dari gel. Penerapan formula untuk bolu sponge dilakukan untuk mengetahui pengaruhnya terhadap berat jenis adonan, ketinggian bolu setelah dipanggang, serta karakteristik struktur pori dan warna crumb bolu melalui evaluasi sensori. Penggunaan 100\% PGE dan penggunaan DMG hingga 50\% tidak memengaruhi karakteristik fisik formula campuran pengemulsi. Aplikasi formula pada bolu sponge tidak memengaruhi specific gravity adonan bolu, ketinggian bolu, serta struktur pori crumb, dan hanya memengaruhi warna crumb bolu.
\end{abstract}

Kata Kunci: bolu sponge, formula pengemulsi, monogliserida terdistilasi, pengemulsi bolu, poligliserol ester

Aplikasi Praktis: Pengaruh penggunaan pengemulsi campuran DMG dan PGE dalam produk bolu sponge terhadap mutu fisik dan sensori produk yang dihasilkan dapat menjadi informasi yang penting untuk diketahui oleh industri bakeri, khususnya industri cake.

\section{PENDAHULUAN}

Pengemulsi (emulsifier) baik tunggal maupun campurannya dapat memperbaiki pembentukan busa adonan bolu sponge yang merupakan foam-type cake (Kohajdova et al. 2009; Orthoefer dan Kim 2019; Wrigley et al. 2016). Apabila tanpa pengemulsi, pembentukan busa adonan bolu sponge bergantung pada pengocokan putih telur secara terpisah sebelum ditambahkan ke dalam bahan adonan lainnya. Adonan bolu sponge terdiri dari tepung terigu rendah protein, telur, dan gula (Caballero et al. 2016) yang dicampur secara mekanis membentuk suatu sistem emulsi kompleks yang memerangkap udara (Chaiya dan Pongsawatmanit 2011) sehingga memiliki nilai berat jenis adonan yang relatif rendah dan berpenampakan seperti busa. Campuran bahan tambahan pangan (BTP) pengemulsi dalam bentuk pasta telah beredar di pasar dengan nomor pendaftaran produk di Badan Pengawas Obat dan Makanan (Badan POM) Jakarta telah diketahui dari 2012 (Sari et al. 2019), 
meskipun peraturan mengenai persyaratan BTP campuran baru disahkan Kepala Badan POM pada tahun 2016 (PerKaBPOM No. 8 Tahun 2016). Hasil studi Sari et al. (2019) melaporkan BTP campuran pengemulsi yang beredar umumnya dalam bentuk pasta atau gel dan mempunyai komposisi BTP primer dan BTP sekunder. BTP primer adalah BTP pengemulsi yang tersedia dalam campuran beberapa pengemulsi untuk mempengaruhi produk akhir seperti bolu sponge. BTP sekunder terdiri dari berbagai jenis BTP yang diperlukan hanya untuk memperoleh sifat sediaan BTP yang dikehendaki (dalam hal ini bentuk gel dan berwarna kuning). Sari et al. (2019) memperinci BTP sekunder dalam BTP campuran pengemulsi yang diperdagangkan terutama sorbitol dan propilenglikol, dengan sedikit pewarna kuning (kuning FCF dan tartrazine) serta pengatur keasaman (asam asetat dan kalsium asetat).

Pengemulsi untuk bolu dapat diperoleh dari formula campuran pengemulsi lengkap dengan BTP lainnya dengan menggunakan $15 \%$ distilled monoglycerides (DMG), 10\% polyglycerol esters (PGE), 20\% sorbitol, $10 \%$ propylene glycol, $10 \%$ glycerol, $0.8 \%$ natrium stearat, $0.5 \% \mathrm{NaOH}, 0.15 \%$ garam halus, dan $33.55 \%$ air (Lee et al. 2014). Campuran pengemulsi DMG dan PGE untuk menghasilkan bolu sponge dengan struktur dan pengembangan yang baik. Campuran tersebut dibuat dalam bentuk gel dengan pelarut polar seperti propilenglikol, sorbitol, dan gliserol yang merupakan BTP sekunder yang memiliki fungsi dalam formula campuran pengemulsi (BTP campuran penemulsi DMG dan PGE) dan tidak diperuntukkan memiliki fungsi teknologi pada produk pangan, sesuai dengan definisi BTP sekunder menurut Codex (2015). PGE berfungsi untuk memastikan DMG tetap dalam format aktif gel fase- $\alpha$. DMG membantu proses aerasi adonan dan melembutkan crumb hanya jika berbentuk alpha-crystalline yang aktif (Lee et al. 2014; Richardson et al. 2002).

Monoglycerides (DMG) dan polyglycerol esters (PGE) memiliki standar warna putih, akan tetapi ketersediaan bahan ini memungkinkan terdapatnya PGE dengan warna coklat kekuningan dan DMG oranye kekuningan. Perubahan warna suatu produk dapat mengindikasikan adanya penyimpangan mutu. Penggunaan pengemulsi baik tunggal ataupun campuran dengan warna yang tidak sesuai dengan standar belum diketahui apakah dapat menurunkan mutu pengemulsi tersebut terutama dalam aplikasinya pada bolu sponge. Selama ini, produk campuran emulsifier yang dipasakan memiliki warna kuning kejinggaan yang transparan dan hal ini telah menjadi ciri khas produk ini yang telah dikenal oleh konsumen, yang menggunakan pewarna makanan dalam formunya. Penggunaan pewarna makanan sintetis dalam jumlah rendah sesuai dengan formulasi existing product diterapkan untuk menutupi perbedaan warna yang terjadi akibat perbedaan warna pengemulsi sebagai bahan baku yang digunakan.

Penelitian ini dilakukan untuk melihat pengaruh formula BTP campuran pengemulsi untuk produk bolu sponge. Penggunaan DMG dan PGE yang memiliki warna, namun tetap menghasilkan formula BTP campuran pengemulsi sesuai dengan standar (standard DMG dan PGE berwarna putih) diharapkan dapat meminimalkan penolakan bahan baku DMG dan PGE yang terjadi di industri pengolah BTP campuran. Formulasi terbaik BTP campuran pengemulsi berdasarkan sifat fisik gelnya selanjutnya diaplikasikan pada pembuatan bolu sponge untuk melihat aplikasi formula pada pembentukan foam adonan sebelum dipanggang dan karakteristik bolu sponge setelah dipanggang.

\section{BAHAN DAN METODE}

\section{Bahan}

Bahan yang digunakan dalam membuat formulasi BTP campuran pengemulsi adalah distilled monoglycerides (DMG) dan polyglycerol esters (PGE) masingmasing berbentuk serbuk produksi Denmark dan Malaysia, campuran stabilizer, gula alkohol (sorbitol) produksi Cina, pewarna makanan sintetis warna kuning (ponceau dan tartrazine) produksi Indonesia dan India, air, dan bahan tambahan pangan pembawa (propilen glikol) produksi Korea. Bahan yang digunakan untuk membuat adonan bolu sponge untuk aplikasi formula diperoleh dari pasar lokal di Tangerang, dan baking powder 'Alpina' produksi PT Seelindo Sejahteratama.

Alat yang digunakan dalam formulasi pengemulsi yaitu termometer alkohol $100^{\circ} \mathrm{C} \pm 1^{\circ} \mathrm{C}$, heater (Daihan Scientific, Korea Selatan), neraca analitik (AND GF3000 dan AND HR-200, Jepang) dengan ketepatan \pm 0.01 $\mathrm{g}$ dan $\pm 0.0001 \mathrm{~g}$, dan alat gelas. Alat yang digunakan dalam pembuatan bolu sponge yaitu oven pemanggang SINMAG (Taiwan) berdaya $380 \mathrm{~V}, 50 \mathrm{~Hz}$, dan $3 \mathrm{PH}$ yang memiliki dua setting suhu (atas dan bawah), varimixer Kitchen Aid (Amerika Serikat) berdaya 220-240V, 50/60 $\mathrm{Hz}$, dan $315 \mathrm{~W}$, loyang alumunium bundar berdiameter $22 \mathrm{~cm}$ dan tinggi $4 \mathrm{~cm}$.

Instrumen yang digunakan untuk anilisis mutu formula pengemulsi yaitu chromameter (Konica Minolta CR-300, Jepang), penetrometer PNR 6 (SUR, Jerman) dengan probe conical-frustum (diameter atas $3 \mathrm{~cm}$, diameter bawah $0.1 \mathrm{~cm}$, tinggi $7 \mathrm{~cm}$ ). Alat yang digunakan untuk menganalisis hasil aplikasi yaitu mangkuk plastik, batter scrapper, dan neraca analitik (AND GF-3000) dengan ketepatan $\pm 0.01 \mathrm{~g}$ untuk menghitung SG adonan, serta penggaris besi $100 \mathrm{~cm}$ untuk mengukur tinggi kue setelah pemanggangan.

\section{Formula BTP campuran pengemulsi}

Penelitian ini diawali dengan formulasi BTP campuran pengemulsi menggunakan campuran dua bahan pengemulsi yang secara visual memiliki warna yang berbeda. Formulasi menggunakan komposisi BTP primer PGE 6.5\%, DMG 15.3\%, BTP sekunder stabilizer, pewarna (ponceau dan tartrazine) dan propilen glikol $25.8 \%$, sorbitol $26.1 \%$, dan air $26.3 \%$. Perlakuan formulasi yang digunakan dibagi ke dalam dua tahap formulasi. Tahap formulasi pengemulsi pertama 
menggunakan campuran pengemulsi PGE berwarna putih (standar) dan berwarna cokelat kekuningan (Pc). Kandungan Pc pada formulasi tahap pertama bertingkat dari 25, 50, 75\%, hingga $100 \%$ dari total penggunaan PGE dalam formulasi BTP campuran pengemulsi. Kontrol yang digunakan yaitu formulasi dengan kandungan Pc 0\% (Tabel 1).

Tahap formulasi pengemulsi kedua menggunakan campuran pengemulsi DMG berwarna putih (standar) dan berwarna oranye kekuningan yang dipadukan dengan formulasi terpilih pencampuran pengemulsi PGE standar dan Pc yang berwarna coklat kekuningan dari formulasi tahap pertama. Formulasi tahap kedua adalah penggunaan pengemulsi DMG standar (Mst) dan pengemulsi DMG berwarna oranye kekuningan (Mk) (Tabel 1) yang dipadukan dengan formulasi terpilih pengemulsi PGE standar dan Pc berwarna cokelat kekuningan dari formulasi tahap pertama. Kandungan Mk yang digunakan bertingkat dari 25, 50, 75\%, hingga $100 \%$ dari total penggunaan DMG dalam formulasi BTP campuran pengemulsi. Kontrol yang digunakan yaitu formulasi dengan kandungan Mk 0\% dan Pc 0\% (Tabel 1). Data yang dianalisis dari penelitian perbedaan mutu yang diakibatkan oleh penggunaan dua bahan pengemulsi yang secara visual memiliki warna yang berbeda dalam pembuatan formula BTP campuran pengemulsi meliputi mutu warna dan spreadability gel dari formula; serta mutu hasil aplikasi dalam pembuatan bolu sponge, yaitu nilai specific gravity (SG) adonan bolu sponge, tinggi tengah bolu sponge, warna dan struktur pori crumb bolu sponge. Analisis yang dilakukan dijelaskan di bawah. Data selanjutnya dianalisis menggunakan One-way Anova dengan uji lanjut Dunnett.

Pembuatan formula pengemulsi dalam skala laboratorium dilakukan dengan mencampurkan bahan-bahan pengemulsi dengan BTP stabilizer, pembawa dan air dengan sorbitol dalam wadah terpisah. Selanjutnya, kedua campuran dipanaskan hingga $90^{\circ} \mathrm{C}$ sebelum dicampurkan ke dalam satu wadah. Campuran selanjutnya terus diaduk hingga menjadi jernih dan dilakukan penuangan ke dalam wadah plastik. Hasil penuangan didiamkan selama 24 jam di suhu ruang sebelum dapat dilakukan pengujian dan analisis mutu formula yang dihasilkan.

\section{Aplikasi formula BTP campuran pengemulsi pada adonan bolu sponge}

Produk hasil formulasi BTP campuran pengemulsi selanjutnya dianalisis mutunya dengan aplikasi pada pembuatan sponge cake (bolu sponge). ke dalam adonan yang berisi telur $360 \mathrm{~g}$, air $27.5 \mathrm{~g}$, tepung terigu rendah protein $150 \mathrm{~g}$, gula pasir $175 \mathrm{~g}$, dan pati jagung $27.5 \mathrm{~g}$ serta baking powder $5 \mathrm{~g}$. Adonan lalu dicampur dengan varimixer menggunakan ballon whisk dengan kecepatan sedang.

Pembuatan bolu sponge menggunakan formula BTP campuran pengemulsi yang ditambahkan (15 g) kemudian dipanggang menggunakan oven pemanggang dengan setting suhu atas $215^{\circ} \mathrm{C}$ dan suhu bawah $165^{\circ} \mathrm{C}$ selama 30 menit. Konsentrasi BTP campuran pengemulsi yang digunakan yaitu $4 \%$ dari total berat adonan bolu sponge. Selanjutnya, nilai SG adonan diukur dengan penimbangan, tinggi bolu setelah empat jam pasca pemanggangan diukur dengan penggaris besi $100 \mathrm{~cm}$, dan struktur crumb dilihat secara visual dan dibandingkan dengan hasil aplikasi BTP campuran pengemulsi kontrol (dari pengemulsi standar berwarna putih).

\section{Analisis warna formula emulsifier}

Formula emulsifier didiamkan selama 24 jam pada suhu ruang untuk membentuk gel yang stabil sebelum dapat dianalisis warnanya dengan chromameter Minolta CR-300. Warna formula produk gel BTP campuran pengemulsi diukur secara objektif menggunakan chromameter dengan penerangan daylight. Sebelum digunakan, chromameter terlebih dahulu distandarisasi menggunakan plate putih standar. Nilai L* (kecerahan), $\mathrm{a}^{*}$ (kemerahan), dan $\mathrm{b}^{*}$ (kekuningan) kemudian didapatkan dari pengukuran warna sampel menggunakan chromameter (Yagiz et al. 2009). Nilai $\Delta \mathrm{E}^{*}$ yang menunjukkan perbedaan warna antar sampel dengan kontrol didapatkan menggunakan rumus sebagai berikut (Rhim et al. 1999).

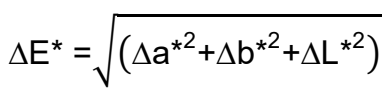

\section{Analisis sensori formula BTP campuran pengemulsi dan crumb bolu sponge}

Warna formula BTP campuran pengemulsi, serta warna dan struktur pori crumb bolu sponge hasil aplikasi produk dianalisis secara kualitatif menggunakan uji sensori R-Index. Uji sensori R-Index efisien digunakan dalam beberapa perbandingan yang melibatkan satu sampel referen dan beberapa sampel uji (Lee dan Van Hout 2009). Uji ini berfokus membedakan antara formula maupun control serta hasil aplikasi dari formulasi pengemulsi Pst dan Pc, maupun pengemulsi Mst dan Mk pada lima level konsentrasi. Panelis terseleksi sejumlah 30 orang digunakan untuk melakukan uji beda dengan satu referen dan lima sampel produk yang diujikan.

Tabel 1. Rasio campuran pengemulsi pada berbagai perlakuan untuk pembuatan BTP campuran pengemulsi

\begin{tabular}{cccccccc}
\hline Tahap & Pengemulsi & Warna Visual & Level 1 (Kontrol) & Level 2 & Level 3 & Level 4 & Level 5 \\
\hline \multirow{2}{*}{1} & Pst (\%) & Putih & 100 & 75 & 50 & 25 & 0 \\
& Pc (\%) & Cokelat kekuningan & 0 & 25 & 50 & 75 & 100 \\
\hline \multirow{2}{*}{2} & Mst (\%) & Putih & 100 & 75 & 50 & 25 & 0 \\
& Mk (\%) & Oranye kekuningan & 0 & 25 & 50 & 75 & 100 \\
\hline
\end{tabular}

Keterangan: ${ }^{\star} \mathrm{P}=$ Polyglycerol esters; $\mathrm{M}=$ Distilled monoglycerides; $\mathrm{st}=$ standar; $\mathrm{Pc}=\mathrm{PGE}$ cokelat kekuningan; Mk = DMG oranye kekuningan 
Familiarisasi terhadap sampel referen dilakukan di awal terlebih dahulu, selanjutnya panelis diminta melakukan identifikasi terhadap sampel produk yang diujikan. Panelis kemudian diminta untuk mengisi kuisioner yang terdiri dari 4 kategori respon berupa "Sama-Yakin", "Sama-Tidak yakin", "Beda-Yakin", "Beda-Tidak Yakin". Data kuisioner yang dikumpulkan selanjutnya dianalisis menggunakan tabel critical values R-Index 50\% dengan One-sided dari penelitian Bi dan O’Mahony (2007). Jika nilai R-Index hitung lebih besar dari nilai R-Index tabel, maka sampel uji berbeda secara signifikan dengan sampel referen. R-Index hitung dari respon panelis dihitung sebagai total nilai Ns (respon stimulus) dari pengujian sampel kontrol dan total $\mathrm{Nn}$ (respon noise) dari pengujian sampel uji.

\section{Analisis spreadibility gel menggunakan penetrometer}

Spreadibility gel dari formula BTP campuran pengemulsi dianalisis setelah didiamkan selama 24 jam pada suhu ruang. Spreadability diukur menggunakan penetrometer dengan probe berbentuk conical-frustum 'kerucut terpotong' (Jaekel dan Ternes 2009). Probe kerucut terpotong yang digunakan tidak ditambah dengan beban tambahan dan waktu penetrasi yang digunakan yaitu 60 detik. Hasil penetrasi dinyatakan dalam penetrasi $/ 10 \mathrm{~mm} / \mathrm{menit}$. Rentang spreadability yang dipersyaratkan yaitu $150-300 / 10 \mathrm{~mm} /$ menit.

\section{Analisis nilai specific gravity adonan}

Nilai specific gravity didapatkan dari rasio antara berat suatu wadah yang berisi adonan dengan berat wadah yang sama yang berisi air distilasi (Psimouli dan Oreopoulou 2013). Adonan sponge cake yang terdiri dari telur, air, tepung terigu protein rendah, gula pasir, pati jagung, dan cake stabilizer dicampur menggunakan ballon whisk dengan kecepatan sedang. Selanjutnya, adonan dituang ke dalam mangkuk kecil yang sudah diketahui berat air yang mengisi penuh volume mangkuk tersebut. Adonan di dalam mangkuk kecil kemudian ditimbang dan dihitung nilai specific gravitynya. Nilai SG yang dipersyaratkan yaitu $0.26-0.33 \mathrm{~g} / \mathrm{mL}$. Perhitungan SG sebagai berikut.

$$
\text { Specific Gravity }(\mathrm{g} / \mathrm{mL})=\frac{\text { Berat adonan kue }}{\text { Berat air }}
$$

\section{Analisis tinggi sponge cake}

Tinggi sponge cake setelah proses pemanggangan adonan ditentukan dengan mengukur tinggi tengah bolu menggunakan penggaris besi $100 \mathrm{~cm}$. Sponge cake didiamkan terlebih dahulu selama 4 jam untuk mendapatkan tinggi yang stabil dan memastikan tidak ada lagi udara panas yang keluar dari bolu sponge. Selanjutnya, bolu yang berbentuk lingkaran dipotong tengahnya dan potongan tersebut ditumpuk. Pengukuran tinggi bolu sponge diukur dari lapisan crumb paling bawah tumpukan pertama hingga lapisan crumb paling atas tumpukan kedua, pada bagian tengah bolu dan dinyatakan dalam $\mathrm{cm}$. Tinggi bolu sponge yang diterima yaitu minimal $9.8 \mathrm{~cm}$.

\section{Analisis data menggunakan one-way ANOVA}

Data mutu formula emulsifier hasil analisis secara fisik dan hasil aplikasi yang meliputi kekerasan gel, warna $\mathrm{L}^{*}, \mathrm{a}^{*}, \mathrm{~b}^{*}$, nilai specific gravity adonan bolu sponge, dan tinggi tengah bolu dianalisis menggunakan One-way Anova dengan uji lanjut Dunnett untuk melihat seberapa jauh formula hasil formulasi berbeda dengan kontrol. Perangkat lunak yang digunakan dalam analisis data yaitu SPSS 20.0.

\section{HASIL DAN PEMBAHASAN}

\section{Formulasi pengemulsi dengan polyglycerol esters berbeda warna}

Pengemulsi polyglycerol esters (PGE) produksi Malaysia yang digunakan dalam penelitian ini memiliki dua warna yang berbeda. PGE standar (Pst) memiliki warna putih, sementara PGE yang tidak diterima sebagai bahan baku $(\mathrm{Pc})$ memiliki warna cokelat kekuningan. Analisis warna menggunakan chromameter pada kedua pengemulsi ini menunjukkan adanya perbedaan warna dengan nilai $\Delta \mathrm{E}^{*}$ sebesar 5.78 (Tabel 2). Tabel 3 menunjukkan hasil analisis warna formula BTP campuran pengemulsi menggunakan chromameter menunjukkan keempat perlakuan formulasi Pc tidak berbeda nyata dengan kontrol pada notasi warna $L^{*}$ dan $a^{*}$. Formulasi level 5 (Pc 100\%) memiliki notasi warna b* yang berbeda nyata dengan kontrol. Hasil uji R-Index memperlihatkan perlakuan formulasi level 2, 4, dan 5 tidak berbeda secara signifikan dengan kontrol (Tabel 2). Korelasi antara nilai R-Index rata-rata (subjektf) dan $\Delta \mathrm{E}$ (objektif) dari semua sampel memiliki $\mathrm{r}^{2}$ sebesar 0.1713, dengan demikian hasil objektif warna diperlukan dalam analisis formula dan hasil aplikasinya.

Daya pisah (spreadability) gel yang terbentuk dari lima formulasi BTP campuran pengemulsi menunjukkan keempat perlakuan formulasi Pc tidak berbeda nyata dengan kontrol pada taraf signifikansi 0.05 (Tabel 2). Bentuk gel pada formula BTP campuran pengemulsi berasal dari penggunaan sorbitol yang berbetuk cairan kental sebagai pelarut polar dan bahan tambahan pangan pembawa (propilen glikol) yang juga bersifat polar. Hasil uji formula BTP campuran pengemulsi formulasi Pc secara fisik menunjukkan jika warna PGE cokelat kekuningan yang digunakan memengaruhi warna formula yang diuji secara objektif, tapi tidak memengaruhi daya pisah gel yang terbentuk. Meski begitu, formula pengemulsi dengan formulasi $100 \%$ Pc dapat diterima.

Tabel 2. Hasil analisis warna pengemulsi PGE (standar warna putih Pst dan yang berwarna cokelat kekuningan $\mathrm{Pc}$ ) dengan chromameter

\begin{tabular}{lccc}
\hline \multicolumn{1}{c}{ Notasi Warna } & Pst & Pc & Perbedaan Warna \\
\hline CIE L* & 39.51 & 37.14 & $\Delta \mathrm{L}^{*}=+2.37$ \\
CIE a $\mathrm{a}^{*}$ & -7.12 & -7.68 & $\Delta \mathrm{a}^{*}=+0.56$ \\
CIE b* & +19.35 & +24.59 & $\Delta \mathrm{b}^{*}=-5.24$ \\
\hline & & & $\Delta \mathrm{E}^{*}=5.78$
\end{tabular}

Keterangan: $\Delta \mathrm{L}^{*}+=$ sampel lebih terang dari standar; $\Delta \mathrm{L}^{*}-=$ sampel lebih gelap dari standar; $\Delta \mathrm{a}^{*}+=$ sampel lebih merah dari standar; $\Delta \mathrm{b}^{*}+=$ sampel lebih kuning dari standar; $\Delta \mathrm{b}^{*}-=$ sampel lebih biru dari standar; $\Delta \mathrm{a}^{*}-=$ sampel lebih hijau dari standar 
Tabel 3. Hasil analisis warna dengan chromameter, spreadability dengan penetrometer (per $10 \mathrm{~mm} / \mathrm{menit}$ ) dan sensori warna R-Index (\%) dari formula pengemulsi PC

\begin{tabular}{|c|c|c|c|c|c|c|}
\hline 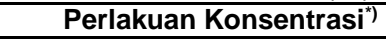 & $L^{*}$ & $a^{*}$ & $\mathbf{b}^{*}$ & $\Delta \mathbf{E}^{\star}$ & Penetrasi & R-Index \\
\hline Level 1 (Pc 0\%) & $42.01 \pm 1.24^{a}$ & $3.73 \pm 0.87^{a}$ & $18.59 \pm 0.82^{a}$ & - & $201.67 \pm 46.52^{a}$ & 50.00 \\
\hline Level 2 (Pc 25\%) & $41.83 \pm 2.21^{a}$ & $3.01 \pm 1.13^{a}$ & $20.99 \pm 1.94^{a}$ & 2.51 & $212.33 \pm 21.78^{a}$ & 47.15 \\
\hline Level 3 (Pc 50\%) & $39.30 \pm 0.67^{a}$ & $4.69 \pm 0.59^{a}$ & $18.85 \pm 0.78^{a}$ & 2.88 & $177.33 \pm 23.76^{a}$ & $\left.62.24^{* *}\right)$ \\
\hline Level 4 (Pc 75\%) & $39.54 \pm 1.11^{a}$ & $4.43 \pm 0.03^{a}$ & $19.58 \pm 0.64^{a}$ & 2.75 & $230.33 \pm 46.76^{a}$ & 57.94 \\
\hline Level 5 (Pc 100\%) & $41.28 \pm 1.77^{a}$ & $3.57 \pm 1.04^{a}$ & $21.67 \pm 0.69^{b}$ & 3.17 & $160 \pm 9.85^{\mathrm{a}}$ & 52.48 \\
\hline
\end{tabular}

Keterangan: *H Huruf subset yang sama pada satu kolom menunjukkan parameter tidak berbeda nyata pada taraf signifikansi $\alpha=0.05$ menurut hasil uji Dunnett; ${ }^{* *}$ Berbeda dari R-Index table $61.92 \%$ pada taraf signifikansi $\alpha=0.05$

Aplikasi formulasi Pc dalam pembuatan sponge cake

Hasil analisis mutu aplikasi formula BTP campuran pengemulsi (Tabel 4) pada adonan bolu sponge memberikan hasil yang tidak berbeda signifikan antara sampel formula dan kontrol, juga sesuai dengan rentang mutu parameter yang dipersyaratkan dalam pengujian formula di industri pangan terkait. Hal ini menandakan jika warna polyglycerol esters sebagai bahan baku formula tidak memengaruhi mutu hasil aplikasinya.

Tabel 4. Mutu aplikasi formula pengemulsi Pc dalam pembuatan bolu sponge

\begin{tabular}{|c|c|c|c|c|}
\hline $\begin{array}{c}\text { Perlakuan } \\
\text { Konsentrasi") }\end{array}$ & $\underset{(g / m L)}{S G}$ & $\begin{array}{l}\text { Tinggi Bagian } \\
\text { Tengah Kue } \\
\text { (cm) }\end{array}$ & $\begin{array}{l}\text { Warna } \\
\text { Crumb }\end{array}$ & $\begin{array}{c}\text { Struktur } \\
\text { Pori } \\
\text { Crumb }\end{array}$ \\
\hline $\begin{array}{l}\text { Level 1 } \\
\text { (Kontrol) }\end{array}$ & $\begin{array}{l}0.31 \pm \\
0.00^{\mathrm{a}}\end{array}$ & $10.2 \pm 0.2^{\mathrm{a}}$ & $\begin{array}{l}\text { Kuning } \\
\text { muda }\end{array}$ & Seragam \\
\hline $\begin{array}{l}\text { Level } 2 \\
\text { (Pc 25\%) }\end{array}$ & $\begin{array}{l}0.32 \pm \\
0.00^{\mathrm{a}}\end{array}$ & $10.2 \pm 0.2^{a}$ & $\begin{array}{l}\text { Kuning } \\
\text { muda }\end{array}$ & Seragam \\
\hline $\begin{array}{l}\text { Level } 3 \\
\text { (Pc 50\%) }\end{array}$ & $\begin{array}{l}0.33 \pm \\
0.00^{\mathrm{a}}\end{array}$ & $9.9 \pm 0.2^{\mathrm{a}}$ & $\begin{array}{l}\text { Kuning } \\
\text { muda }\end{array}$ & Seragam \\
\hline $\begin{array}{l}\text { Level } 4 \\
\text { (Pc 75\%) }\end{array}$ & $\begin{array}{l}0.31 \pm \\
0.02^{\mathrm{a}}\end{array}$ & $10.3 \pm 0.1^{a}$ & $\begin{array}{l}\text { Kuning } \\
\text { muda }\end{array}$ & Seragam \\
\hline $\begin{array}{l}\text { Level } 5 \\
\text { (Pc 100\%) }\end{array}$ & $\begin{array}{l}0.32 \pm \\
0.00^{\mathrm{a}}\end{array}$ & $10.2 \pm 0.2^{a}$ & $\begin{array}{l}\text { Kuning } \\
\text { muda }\end{array}$ & Seragam \\
\hline
\end{tabular}

Keterangan: *Huruf subset yang sama menunjukkan parameter tidak berbeda nyata pada taraf signifikansi $\alpha=0.05$

Struktur pori crumb bolu sponge keempat perlakuan (Gambar 1) memiliki struktur pori yang tingkat keseragamannya tidak berbeda nyata. Dengan demikian perbedaan warna formula pengemulsi tidak memengaruhi mutu crumb bolu sponge. Keseragaman struktur pori akan menghasilkan bolu sponge yang lembut dan memiliki permukaan crumb yang halus. Keseragaman pori dipengaruhi oleh proses aerasi yang terjadi pada tahap pencampuran adonan. Pengemulsi berperan dalam pembentukan sel udara yang kecil dan seragam sehingga membentuk struktur pori yang seragam pada saat udara dilepaskan dalam proses pemanggangan (Zhou et al. 2011).

\section{Fomulasi BTP campuran pengemulsi dengan distilled monoglycerides berbeda warna}

Pengemulsi distilled monoglycerides (DMG) produksi Denmark yang digunakan dalam penelitian ini juga memiliki dua warna yang berbeda. DMG standar (Mst) memiliki warna putih, sementara pengemulsi yang akan diuji lebih lanjut memiliki warna oranye kekuningan (Mk). Analisis warna menggunakan chromameter pada kedua DMG menunjukkan adanya perbedaan warna dengan nilai $\Delta E^{*}$ sebesar 6.81 (Tabel 5). Pengecekan pengaruh warna Pc sebagai bahan baku dengan empat formulasi perlakuan pada penelitian tahap satu menghasilkan formulasi terpilih yaitu formulasi level 5 (Pc 100\%). Selanjutnya, dibuat lima level konsentrasi (Tabel 6) yang mencampurkan formulasi Pc $100 \%$ dengan Mk untuk melihat pengaruh warna emulsifier Pc dan Mk terhadap mutu produk formula emulsifier. Hasil analisis warna (Tabel 6) menunjukkan jika formulasi level 4 (Mk 75\%) dan formulasi level 5 ( Mk 100\%) berbeda signifikan dengan kontrol pada notasi warna $b^{*}$. Perbedaan warna ini dapat dilihat melalui nilai $\Delta \mathrm{E}^{*}$. Nilai $\Delta E^{*}$ sampel level 3 sebesar 3.15. Nilai $\Delta E^{*}$ level 4 dan level 5 keduanya lebih dari 3.17 (nilai yang dapat diterima untuk industri pangan), yaitu 3.50 dan 4.68. Perbedaan warna yang terjadi antara kontrol (level 1) dan formula Mk level 4 (75\%) dan level 5 (100\%) secara obyektif cukup jauh dan dapat dibedakan secara visual.

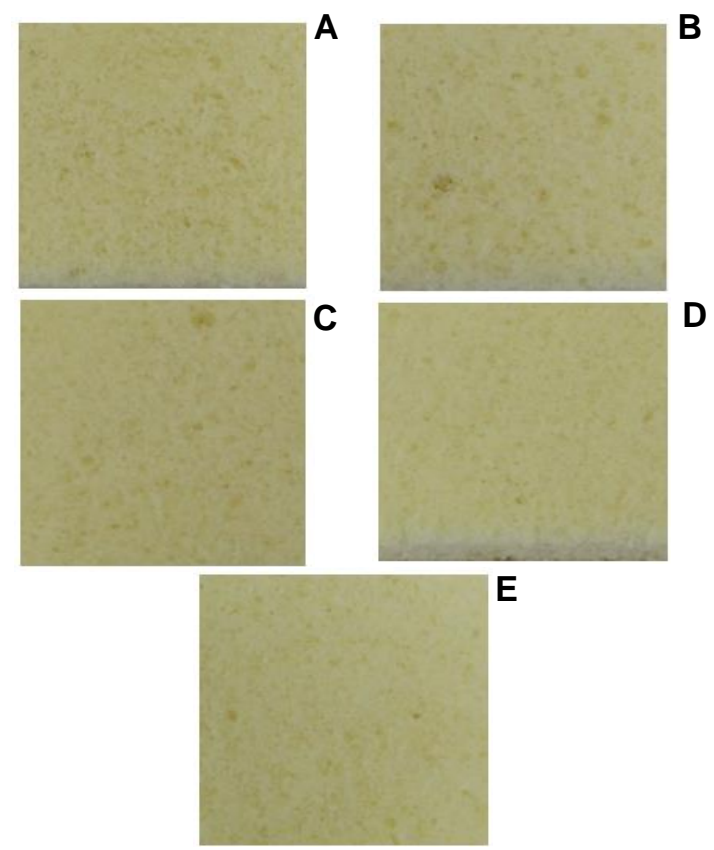

Gambar 1. Struktur pori crumb bolu sponge formulasi Pc pada pembesaran yang sama (a: kontrol, b: level 2, c: level 3, d: level 4, e: level 5)

Tabel 5. Hasil analisis warna pengemulsi DMG dengan chromameter

\begin{tabular}{cccc}
\hline Notasi Warna & Mst & Mk & Perbedaan Warna \\
\hline CIE L $^{*}$ & 83.38 & 87.92 & $\Delta \mathrm{L}^{*}=-4.54$ \\
CIE $\mathrm{a}^{*}$ & +1.69 & -0.81 & $\Delta \mathrm{a}^{*}=+2.50$ \\
CIE b* & +10.58 & +6.15 & $\Delta \mathrm{b}^{*}=+4.43$ \\
\hline & & $\Delta \mathrm{E}^{*}=6.81$ \\
\hline
\end{tabular}

Hasil uji warna formulasi pengemulsi Mk secara objektif sesuai dengan hasil uji sensori warna menggunakan metode R-Index (Tabel 6) di mana perlakuan level 3, level 4 dan level 5 berbeda secara signifikan 
dengan kontrol. Keempat sampel secara visual memiliki warna jingga kekuningan atau merah-kuning, namun panelis terseleksi dapat membedakan kekeruhan yang terjadi pada sampel formula pengemulsi level 3, 4, dan 5 . Kekeruhan yang terjadi sesuai dengan nilai $\Delta \mathrm{b}^{*}$ sampel level 4 dan 5 yang bernilai negatif (sampel lebih biru dari kontrol). Korelasi antara hasil uji warna formula secara ojektif dengan parameter $\Delta \mathrm{E}$ dan nilai $\mathrm{R}$-Index rata-rata memiliki nilai $\mathrm{r}^{2}$ sebesar 0.7678 .

Uji spreadability gel formula BTP Campuran pen gemulsi menunjukkan keempat formulasi $\mathrm{Mk}$ tidak berbeda nyata dengan kontrol (Tabel 6). Hal ini menunjukkan jika warna bahan pengemulsi DMG tidak memengaruhi daya pisah gel yang terbentuk. Spreadability gel formula BTP campuran pengemulsi dipengaruhi oleh kepolaran bahan pembawa yang digunakan dan banyaknya air yang terdapat dalam komposisi (Van de Walle et al. 2008).

\section{Aplikasi formulasi BTP campuran pengemulsi dari mk dalam pembuatan sponge cake}

Mutu hasil aplikasi formula BTP campuran pengemulsi perlakuan formulasi Mk pada pembuatan bolu sponge menunjukkan keempat formulasi $\mathrm{Mk}$ tidak berbeda secara signifikan dalam parameter nilai SG dan tinggi tengah kue (Tabel 7). Nilai specific gravity adonan sponge cake dari hasil aplikasi keempat perlakuan formulasi Mk berkisar antara $0.30-0.31 \mathrm{~g} / \mathrm{mL}$, dan tidak berbeda secara signifikan dengan kontrol $(0.30 \mathrm{~g} / \mathrm{mL})$. Karena nilai SG adonan keempat perlakuan memiliki rentang yang sempit $(0.30-0.31 \mathrm{~g} / \mathrm{mL})$, maka nilai tinggi tengah kue yang diperoleh juga memiliki kisaran sempit $10.0-10.1 \mathrm{~cm}$. Struktur pori crumb sponge cake keempat perlakuan (Gambar 2) memiliki struktur pori yang tingkat keseragamannya tidak berbeda nyata. Menurut uji RIndex yang dilakukan untuk menilai struktur pori dan warna crumb, struktur pori crumb keempat perlakuan formulasi Mk seragam dan tidak berbeda nyata dengan kontrol, sementara warna crumb bolu sponge hasil aplikasi formulasi level 2, 3, dan 5 memiliki warna yang berbeda dengan kontrol. Hal ini dapat disebabkan warna formulasi Mk level 3 dan 5 yang lebih gelap dari kontrol sehingga memengaruhi warna hasil aplikasi bolu sponge yang dibuat. Hasil penelitian ini menunjukkan bahwa DMG yang merupakan pengemulsi utama (15\% dari total formula emulsifier) dengan PGE (hampir separuh dari DMG) memberikan mutu bolu sponge, khususnya volume bolu dan struktur crumb, yang diharapkan. Hasil ini sejalan dengan hasil yang dikemukakan oleh $\mathrm{Fu}$ et al. (2018).

Tabel 7. Mutu aplikasi formulasi BTP campuran pengemulsi Mk dalam pembuatan sponge cake

\begin{tabular}{|c|c|c|c|c|}
\hline $\begin{array}{c}\text { Perlakuan } \\
\text { Konsentrasi`) }\end{array}$ & $S G(g / m L)$ & $\begin{array}{c}\text { Tinggi } \\
\text { Bagian } \\
\text { Tengah } \\
\text { Kue (cm) }\end{array}$ & $\begin{array}{l}\text { Warna } \\
\text { Crumb }\end{array}$ & $\begin{array}{c}\text { Struktur } \\
\text { Pori } \\
\text { Crumb }\end{array}$ \\
\hline $\begin{array}{l}\text { Level 1 } \\
\text { (Kontrol) }\end{array}$ & $0.31 \pm 0.01^{a}$ & $10.1 \pm 0.2^{a}$ & $\begin{array}{l}\text { Kuning } \\
\text { muda }\end{array}$ & Seragam \\
\hline $\begin{array}{l}\text { Level } 2 \\
\text { (Mk 25\%) }\end{array}$ & $0.30 \pm 0.02^{a}$ & $10.1 \pm 0.2^{a}$ & $\begin{array}{l}\text { Kuning } \\
\text { muda* }^{*}\end{array}$ & Seragam \\
\hline $\begin{array}{l}\text { Level } 3 \\
\text { (Mk 50\%) }\end{array}$ & $0.31 \pm 0.02^{a}$ & $10.1 \pm 0.2^{a}$ & $\begin{array}{l}\text { Kuning } \\
\text { muda* }\end{array}$ & Seragam \\
\hline $\begin{array}{l}\text { Level } 4 \\
\text { (Mk 75\%) }\end{array}$ & $0.31 \pm 0.02^{a}$ & $10.0 \pm 0.1^{a}$ & $\begin{array}{l}\text { Kuning } \\
\text { muda }\end{array}$ & Seragam \\
\hline $\begin{array}{l}\text { Level } 5 \\
\text { (Mk 100\%) }\end{array}$ & $0.31 \pm 0.01^{a}$ & $10.1 \pm 0.1^{a}$ & $\begin{array}{l}\text { Kuning } \\
\text { muda* }^{*}\end{array}$ & Seragam \\
\hline
\end{tabular}

Keterangan: *) Huruf subset yang sama menunjukkan parameter tidak berbeda nyata pada taraf signifikansi $\alpha=0.05$ menurut hasil uji Dunnett; * Melambangkan berbeda signifikan dengan referen uji sensori metode RIndex pada taraf signifikansi $\alpha=0.05$

\section{KESIMPULAN}

Warna polyglycerol esters dan distilled monoglycerides sebagai bahan baku pengemulsi memengaruhi warna formula BTP campuran pengemulsi. Warna formula ini memengaruhi warna crumb bolu sponge yang dapat dibedakan oleh panelis terseleksi dalam uji sensori menggunakan metode R-Index. Meskipun demikian, spreadability gel formula BTP campuran pengemulsi, nilai $S G$ adonan bolu sponge dan tinggi tengah kue tidak dipengaruhi oleh warna polyglycerol esters dan distilled monoglycerides. Formulasi terpilih yang dapat digunakan untuk mengurangi penolakan bahan baku pengemulsi PGE dan DMG yaitu penggunaan $100 \%$ PGE cokelat kekuningan dengan penggunaan 25\% DMG orange kekuningan.

Tabel 6. Hasil analisis warna dengan chromameter, spreadability dengan penetrometer (per $10 \mathrm{~mm} / \mathrm{menit}$ ) dan sensori warna $\mathrm{R}-$ Index (\%) dari formula emulsifier $\mathrm{Mk}$

\begin{tabular}{|c|c|c|c|c|c|c|}
\hline $\begin{array}{c}\text { Perlakuan } \\
\left.\text { Konsentrasi }{ }^{\star}\right)\end{array}$ & $\mathbf{L}^{*}$ & $a^{\star}$ & $\mathbf{b}^{*}$ & $\Delta \mathbf{E}^{*}$ & Penetrasi & R-Index \\
\hline Level 1 (Mk 0\%) & $40.77 \pm 0.62^{a}$ & $5.87 \pm 0.14^{a}$ & $22.53 \pm 1.56^{\mathrm{a}}$ & - & $185.33 \pm 8.08^{a}$ & 50.0 \\
\hline Level 2 (Mk 25\%) & $39.31 \pm 0.55^{a}$ & $5.53 \pm 0.83^{a}$ & $20.81 \pm 1.45^{a}$ & 2.29 & $174.67 \pm 2.89^{a}$ & 55.42 \\
\hline Level 3 (Mk 50\%) & $39.80 \pm 0.27^{a}$ & $5.39 \pm 0.48^{a}$ & $19.58 \pm 1.27^{a}$ & 3.15 & $202.67 \pm 17.47^{a}$ & $\left.63.53^{* \star}\right)$ \\
\hline Level 4 (Mk 75\%) & $39.22 \pm 0.97^{a}$ & $6.59 \pm 0.69^{a}$ & $19.48 \pm 0.80^{b}$ & 3.50 & $196.67 \pm 21.63^{a}$ & $\left.84.13^{* \star}\right)$ \\
\hline Level 5 (Mk 100\%) & $40.36 \pm 0.54^{a}$ & $6.78 \pm 0.39^{a}$ & $17.96 \pm 1.20^{b}$ & 4.68 & $179.33 \pm 6.11^{a}$ & $\left.89.26^{* \star}\right)$ \\
\hline
\end{tabular}

Keterangan: ${ }^{*}$ Huruf subset yang sama pada satu kolom menunjukkan parameter tidak berbeda nyata pada taraf signifikansi $\alpha=0.05$ menurut hasil uji Dunnett; ${ }^{* *}$ Berbeda dari R-Index table $61.92 \%$ pada taraf signifikansi $\alpha=0.05$
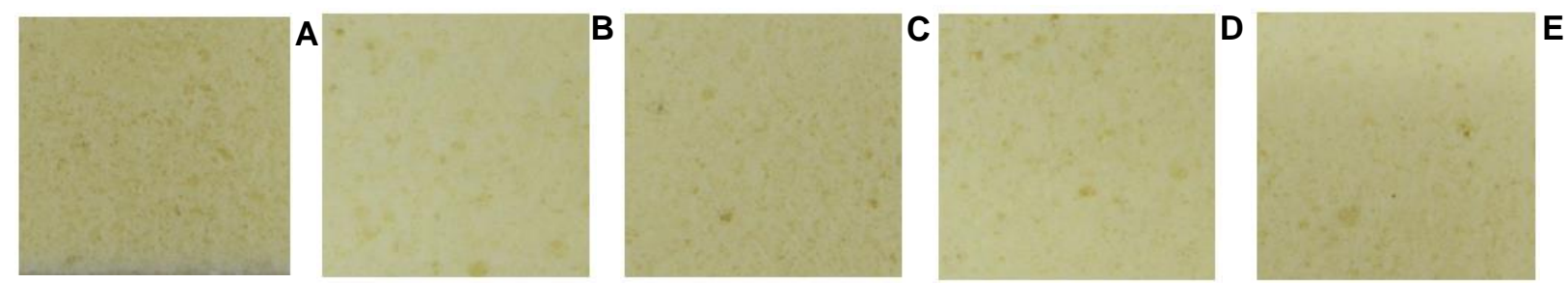

Gambar 2. Struktur pori crumb sponge cake formulasi BTP campuran pengemulsi Mk pada pembesaran yang sama (a: kontrol, b: level 2, c: level 3, d: level 4, e: level 5) 


\section{DAFTAR PUSTAKA}

Bi J, O’Mahony M. 2007. Updated and extended table for testing the significance of the R-index. J Sensory Studies 22(6): 713-720. DOI: 10.1111/j. 1745459X.2007.00132.x.

[BPOM] Badan Pengawas Obat dan Makanan. 2016. Peraturan Kepala Badan Pengawas Obat dan Makanan Republik Indonesia Nomor 8 Tahun 2016 Tentang Persyaratan Bahan Tambahan Pangan Campuran. Jakarta: BPOM.

Caballero B, Finglas PM, Toldra F (eds). 2016. Encyclopedia of Foood and Health. Oxford (UK): Elsevier.

Chaiya B, Pongsawatmanit R. 2011. Quality of batter and sponge cake prepared from wheat-tapioca flour blends. Kasetsart J Nat Sci 45(2): 305-313.

Codex Committee on Food Additives. 2015. Dis-cussion Paper on Secondary Food Additives. Agenda item 8, CX/FA 15/47/19. Rome (Italy): Codex Alimentarius Commission. http://www.fao.org/tempref/codex/ Meetings/CCFA/ccfa47/fa47_19e.pdf (3 Juni 2020)

Fu Y, Zhao R, Zhang L, Bi Y, Zhang H, Chen G. 2018. Influence of acylglycerol emulsifier structure and composition on the function of shortening in layer cake. Food Chem 249: 213-221. DOI: 10.1016/j. foodchem.2017.12.051.

Jaekel T, Ternes W. 2009. Changes in rheological behaviour and functional properties of hen's egg yolk induced by processing and fermentation with phospholipases. Int J Food Sci Technol 44(3): 567573. DOI: 10.1111/j.1365-2621.2008.01847. x.

Kohajdova Z, Karovicova J, Schmidt S. 2009. Significance of emulsifiers and hydrocolloids in bakery industry. Acta Chimica Slovaca 2(1): 46-61.

Lee HS, Van Hout D. 2009. Quantification of sensory and food quality: the R-index analysis. J Food Sci 74(6): 57-64. DOI: 10.1111/j.1750-3841.2009.01 204.x.

Lee LY, Chin NL, Lim CH, Yusof YA, Talib RA. 2014. Saturated distilled monoglycerides variants in gelform cake emulsifiers. Agriculture Agr-cultural Sci Proced 2: 191-198. DOI: 10.1016/j.aaspro.2014.11. 027.

Orthoefer F, Kim D. 2019. Applications of Emulsifiers in Baked Foods. In Emulsifiers and Their Applications. Hasenhuettl GL, Hartel, RW (Eds). Spri- nger: Switzerland. Pp. 299-321. DOI: 10.10 07/ 9783-030-29187-7_10.

Psimouli V, Oreopoulou V. 2013. The effect of fat replacers on batter and cake properties. J Food Sci 78(10): 1495-1502. DOI: 10.1111/1750-3841.12 235.

Richardson G, Langton M, Faldt P, Hermansson AM. 2002. Microstructure of $\alpha$-crystalline emulsifiers and their influence on air incorporation in cake batter. J Cereal Chem 79(4): 546-552. DOI: 10.1094/CCHEM.2002.79.4.546.

Rhim J, Wu Y, Weller C, Schenpf M. 1999. Physical characteristics of a composite film of soy protein isolate and propyleneglycol alginate. J Food Sci 64(1): 149-152. DOI: 10.1111/j.1365-2621.1999. tb09880.x.

Sahi SS, Alava JM. 2003. Functionality of emulsifiers in sponge cake production. J Sci Food Agric 83: 14191429. DOI: $10.1002 /$ jsfa. 1557.

Sari DM, Andarwulan N, Fardiaz D. 2019. Profil komposisi BTP campuran, pelabelan, dan penggunaannya pada industri rumah tangga pangan (IRTP) di DKI Jakarta. J Mutu Pangan 6(1): 38-45. DOI: 10.29244/jmpi.2019.6.38.

Van de Walle D, Goossens P, Dewettinck K. 2008. Influence of sodium soap and ionic strength on the mesomorphic behavior and the a-gel stability of a commercial distilled monoglyceride. Food Res Int 41(3): 247-254. DOI: 10.1016/j.foodres.2007.12. 001.

Wrigley C, Corke H, Seetharaman K, Faubion J. 2016. Encyclopedia of Food Grains, 2 ${ }^{\text {nd }}$ Edition. Oxford (UK): Elsevier.

Yagiz Y, O Balaban M, Kristinsson HG, Welt BA, Marshall MR. 2009. Comparison of Minolta colorimeter and machine vision system inmeasuring colour of irradiated Atlantic salmon. J Sci Food Agric 89(4): 728-730. DOI: 10.1002/jsfa. 3467.

Zhou J, Faubion JM, Walker CE. 2011. Evaluation of different types of fats for use in high-ratio layer cakes. LWT-Food Sci Technol 44(8): 1802-1808. DOI: 10.1016/j.lwt.2011.03.013.

JMP-02-20-03-Naskah diterima untuk ditelaah pada 26 Maret 2020. Revis makalah disetujui untuk dipublikasi pada 13 April 2020. Versi Online: http://journal.ipb.ac.id/index.php/jmpi 